УДК 339.138:338.46

DOI: https://doi.org/10.37320/2415-3583/11.9

\author{
Вовчанська О.М. \\ кандидат економічних наук, доцент, \\ Львівський торговельно-економічний університет \\ ORCID: https://orcid.org/0000-0001-8005-345X
}

Іванова Л.О.

кандидат економічних наук, доцент, Львівський державний університет фізичної культури імені Івана Боберського ORCID: https://orcid.org/0000-0001-5125-0630

\title{
МАРКЕТИНГОВІ ДОСЛІДЖЕННЯ РИНКУ ПОСЛУГ: МІЖНАРОДНІ ТА НАЦІОНАЛЬНІ АСПЕКТИ
}

Стаття присвячена ідентифікації структурних змін на світовому ринку послуг у міжнародному та національних аспектах. Маркетинговими дослідженнями підтверджено посилення ролі послуг у сучасній економіці. Здійснено аналіз динаміки експорту та імпорту послуг у макрорегіонах світу та у краӥнах різного рівня економічного розвитку. Укладено та проаналізовано рейтинг краӥн за показниками експорту та імпорту на світовому ринку послуг. Проаналізовано структурні зміни світового ринку послуг. Досліджено структуру експорту та імпорту послуг в Україні. Наголошується, щео пандемія COVID-19 негативно вплине на світовий ринок послуг, а його відновлення вимагатиме ефективних економічних і політичних заходів, поглиблення співпраці між краӥнами та зниження бар'єрів у взаємній торгівлі найперспективнішими і швидко зростаючими видами послуг.

Ключові слова: послуга, світовий ринок, міжнародна торгівля, експорт послуг, імпорт послуг, маркетингові дослідження.

Постановка проблеми. Не тільки у світовій економіці, але і в економічному зростанні багатьох країн послуги мають велике значення. На послуги припадає близько двох третин обсягів світового виробництва, 75\% загальної зайнятості, майже чверть світової торгівлі. Технологічний прогрес призвів до зростання обсягу сучасних послуг, таких як комунікації, фінансові послуги, послуги інтелектуальної власності. Світова економіка стає економікою послуг, і це не може не позначатися на світовій торгівлі. Торгівля послугами розвивається швидшими темпами, ніж міжнародна торгівля загалом. Якщо ринок послуг зріс удвоє за 7-8 років, то таке зростання світового товарного експорту відбулося за 15 років. У 2005-2017 рр. щорічне збільшення продажу товарів становило 4,6\%, тоді як щорічне зростання торгівлі послугами - 5,4\%. У 1998 р. загальний обсяг світового ринку послуг становив \$1,31 трлн, а у 2017 p. досягнув $\$ 13,3$ трлн, тобто збільшився у десять разів, а до 2040 року, за прогнозом СОТ, перевищить \$20 трлн

Активно впливаючи на економіку, сфера послуг в індустріально розвинених країнах домінує у формуванні ВВП, зайнятості робочої сили, кінцевому споживанні домогосподарств i, врешті, комфорті життя людей. Частка сектору послуг в національних господарствах варіюється від 49\% в країнах Південної Азії до 77\% в Північній Америці і постійно зростає. Хоча розвинені економіки продовжують демонструвати основну частину пропозиції та попиту на ринку послуг, але пока- зово, що частка послуг в економіці країн, що розвиваються, також демонструє зростаючу тенденцію. Величезна і постійно зростаюча розмаїтість ринків послуг включно з географічними і галузевими сегментами постійно генерує нові можливості для комерційної діяльності на цих ринках.

Аналіз останніх досліджень і публікацій. Різноаспектним дослідженням світового ринку послуг присвячені праці багатьох дослідників, зокрема Л.Г. Агафонової, Ф. Котлера, О.П. Кірєєва, Д.Г. Лук'яненко, А.П. Румянцева, Ю.С. Коваленко, А.О. Олефіра, А.О. Старостіної, А.С. Філіпенко, А.П. Челенкова та ін. Проте проблематика світового ринку послуг продовжує викликати підвищену зацікавленість та вимагає грунтовного його дослідження. В умовах викликів сьогодення $\epsilon$ потреба у комплексній маркетинговій оцінці тенденцій розвитку світового ринку послуг за кількісними та якісними параметрами для розуміння складнощів і можливостей України щодо іiі інтеграції у цей сегмент світової економіки.

Метою статті $\epsilon$ ідентифікація структурних змін на світовому ринку послуг у міжнародному та національних аспектах, визначення основних тенденцій його розвитку.

Виклад основного матеріалу. Сфера послуг у сучасній економіці утворює ядро постіндустріальної економіки і значною мірою визначає основні iii макроекономічні параметри. За даними $\mathrm{OOH}$, експорт послуг охоплює майже четверту частину загальносвітового експорту товарів і послуг, тобто завдяки технологічному розвитку саме експорт 
нематеріальних послуг, а не переміщення фізичних товарів стає основою світової торгівлі. Водночас на світовому ринку тривалий час невирішена проблема щодо особливостей статистичного обліку послуг. Недавнє дослідження Глобального інституту McKinsey показує, що в останнє десятиліття темпи зростання міжнародної торгівлі послугами у 60 разів перевищували темпи зростання торгівлі товарами, і вже у 2017 р. на послуги припадало більш ніж половина всієї доданої вартості в глобальних торговельних ланцюгах [5].

Зв'язок між зростанням послуг та загальним економічним зростанням зміцнився за останні два десятиліття, коли середній внесок послуг у ВВП та додану вартість зростав. У 2017 р. додана вартість послуг становила вже 69,8 \% ВВП у країнах з високим рівнем доходу порівняно 3 65\% у 1997 p. Вклад доданої вартості послуг у ВВП був вищим у США, ніж серед інших країн, що мають такий же дохід на душу населення. Зростання частки послуг у ВВП було ще помітнішим у країнах 3 низьким та середнім рівнем доходу, де він зріс 3 $45,1 \%$ у 1997 р. до $53,8 \%$ у 2017 р. (рис. 1 ).

Особливістю торгівлі послугами є зростання їхньої частки в загальних споживчих витратах населення [1]. Така тенденція привела до того, що з 1990 р. по 2016 р. частка сфери послуг у створенні світового ВВП зросла $361,4 \%$ до $67 \%$. У США, наприклад, вона становить майже $60 \%$ i надає робочі місця $77 \%$ населення.

Дослідження показують, що у всіх країнах світу, що належать до різних типів економік, протягом останніх десятиліть спостерігається одна і та ж закономірність: зі зростанням рівня доходу на душу населення зростає частка сектора послуг в структурі ВВП і зменшуються частки інших секторів - промисловості і сільського господарства. Таким чином, розвиток сфери послуг і національної економіки - взаємозалежні явища, позаяк розвиток економіки країни стимулює розвиток сфери послуг, а сфера послуг своєю чергою покращує продуктивність праці, що підвищує ефективність виробництва, а значить, активізує економічне зростання.

Аналогічний результат спостерігається щодо загальнодержавного аналізу послуг, що додаються в загальну додану вартість. За винятком кількох великих країн, що розвиваються, таких як Індонезія, Китай та Індія, сфера послуг внесла понад 60\% загальної доданої вартості у 2017 р. у всіх великих економіках [8; 9]. Зростання обсягів сфери послуг привело до зростання зайнятості. Насправді для більшості країн світу сфера послуг сьогодні $\epsilon$ найбільшим роботодавцем. В усіх країнах-членах Організації економічного співробітництва та розвитку (ОЕСР) понад 70\% зайнятої робочої сили працювало у сфері послуг у 2017 р.; серед промислово розвинених країн-членів ОЕСР 3 високим рівнем доходу, окрім Греції, ця частка перевищувала $80 \%$ (рис. 2).

Як бачимо 3 даних, наведених на рис. 3, за підсумками 2018 р. обсяг світового ВВП становив майже $\$ 86$ трлн, а частка торгівлі послугами - 13,31\%. Частка експорту послуг у ВВП збільшилася до 6,80\% порівняно з 3,32\% у 1980 р. та $4,95 \%$ у 2000 p.

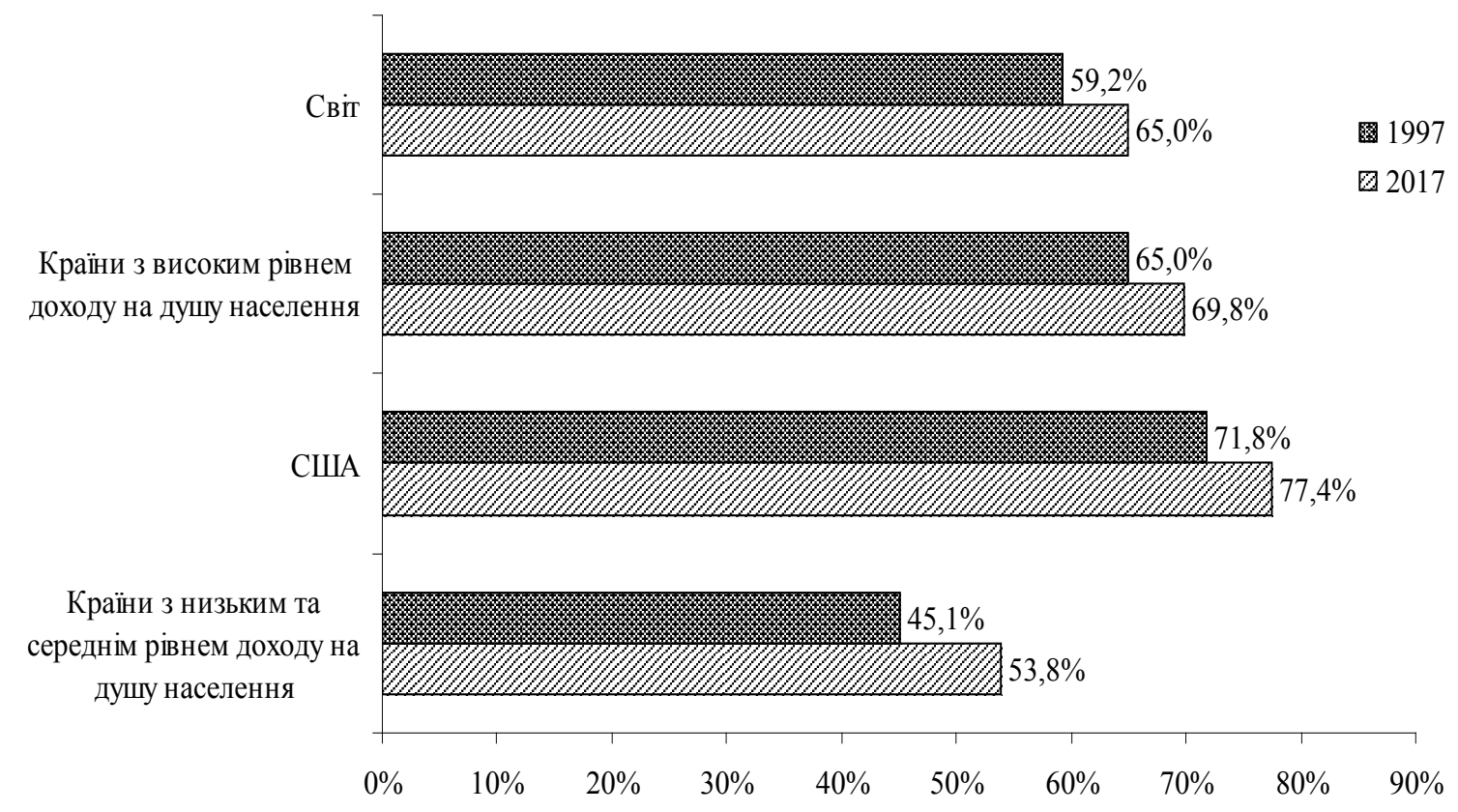

Рисунок 1 - Динаміка частки доданої вартості послуг у ВВП, \% 


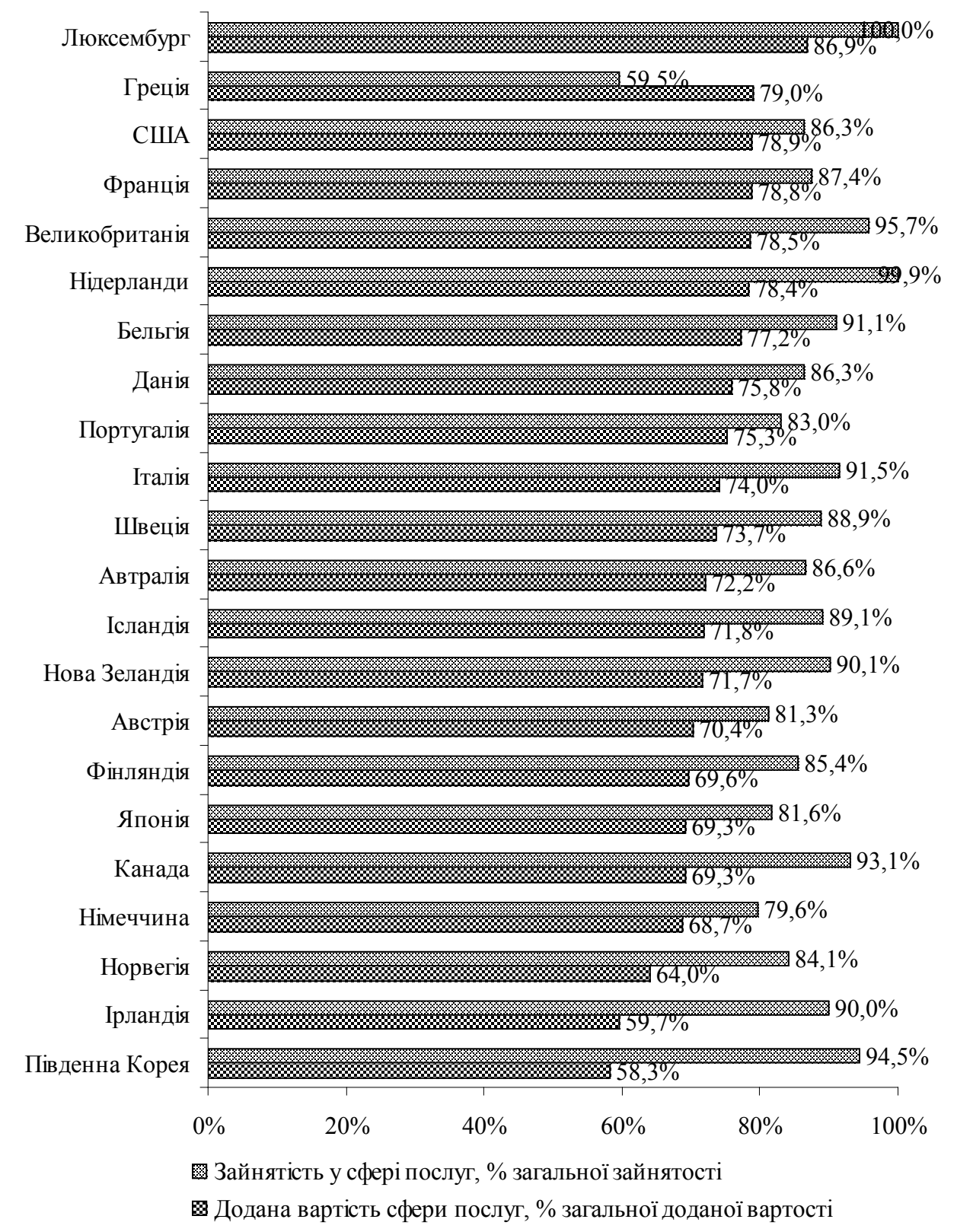

\section{Рисунок 2 - Додана вартість сфери послуг і зайнятість у сфері послуг в окремих країнах ОЕСР у 2017 p.}

Джерело: побудовано за даними [13]

Після значного зростання на 7,9\% у 2017 р. та 7,7\% у 2018 р. за підсумками 2019 р. у глобальній торгівлі послугами очікується повільне зростання на 2,7\%. У 2018 р. світовий експорт послуг оцінювався у $\$ 5,802$ трлн, що становить $7 \%$ світового ВВП. Маркетингові дослідження показують, що динаміка експорту послуг зростала швидше, ніж експорт товарів, як у розвинених, так і в країнах, що розвиваються (ріст на $12 \%$ порівняно з експортом товарів на суму $\$ 5,181$ трлн). Варто зазначити, що експорт послуг має стійкіший характер, ніж експорт товарів, оскільки його максимальне скорочення припало на періоди глобальної еконо- мічної та фінансової кризи 2009 р. і зменшення обсягів торгівлі у 2015 р. Експорт послуг становив 30\% від загального експорту товарів і послуг $\$ 19,347$ трлн у 2018 р. За результатами 2019 р. світовий експорт послуг становив $\$ 6,03$ трлн

У 2018 р. в багатьох економіках Свропи, Центральної Америки, Карибського басейну та Південно-Східної Азії послуги, що продаються на міжнародному рівні, становили понад $10 \%$ ВВП. Деякі менші європейські економіки, такі як Люксембург, Мальта чи Ірландія, та кілька острівних економік, такі як Аруба, Антигуа та Барбуда чи Сейшели, значною мірою покладаються на екс- 


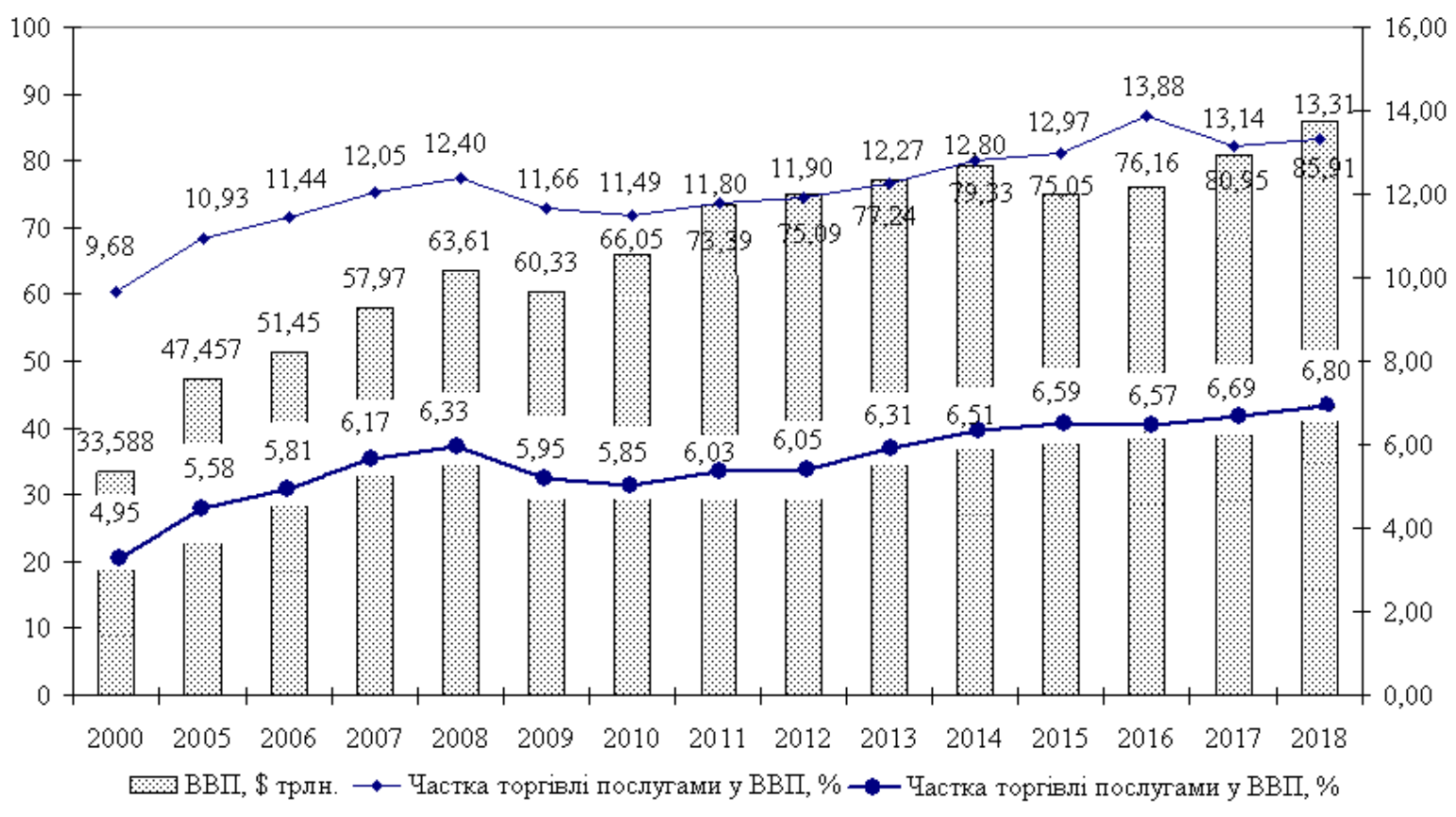

Рисунок 3 - Динаміка обсягів світового ВВП та частки торгівлі послугами в ньому у 2000-2018 pp.

Джерело: побудовано за даними [13]

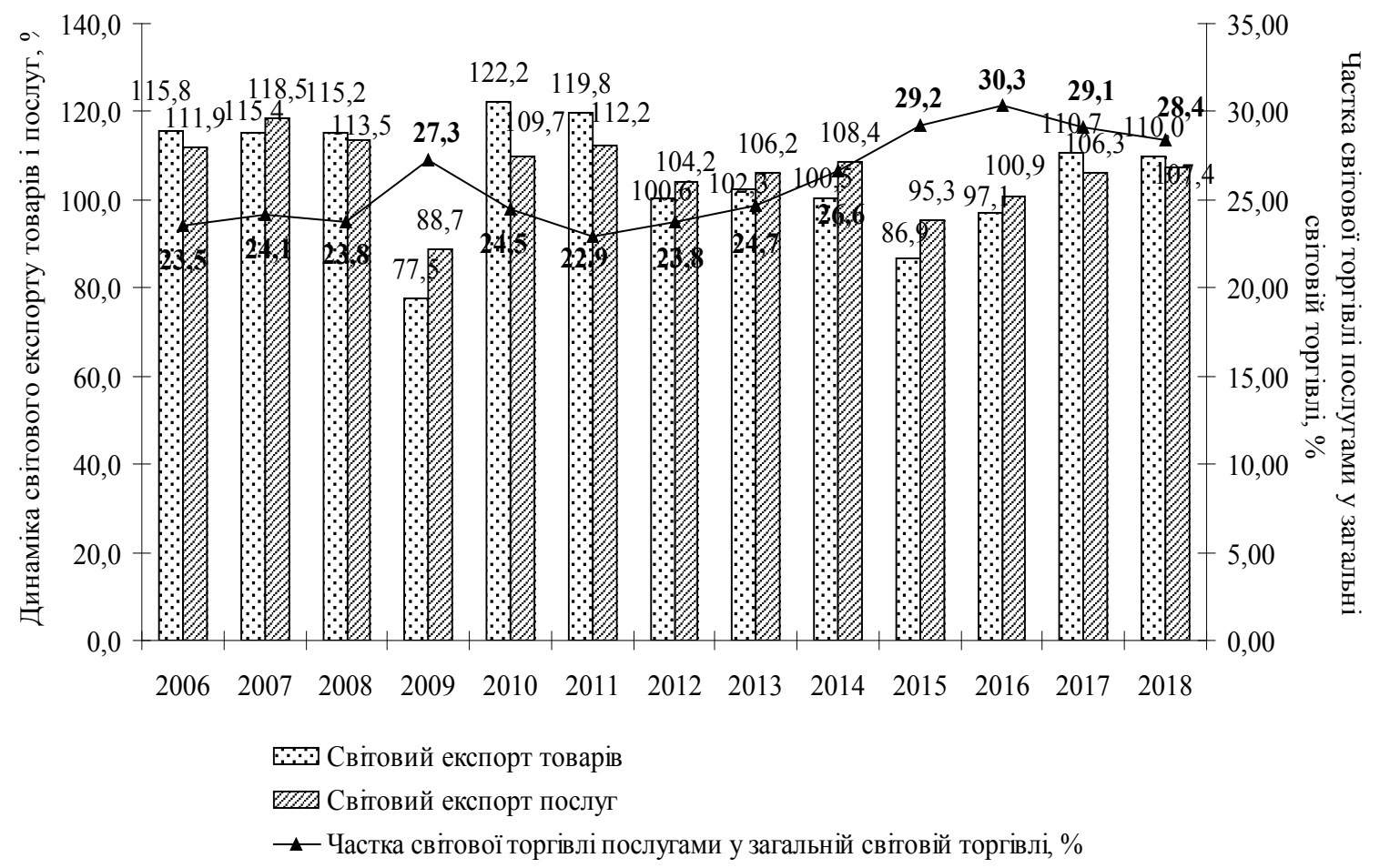

Рисунок 4 - Динаміка світового експорту товарів і послуг, \%

Джерело: розраховано та побудовано за даними [15] 
порт послуг. Навпаки, у великих районах Південної Америки, Західної та Центральної Африки, а також Західної та Східної Азії експорт послуг становив менше 3\% ВВП [10].

У 2006-2018 рр. найвищі темпи приросту експорту товарів спостерігалися у 2010 р. (22,6\%), а послуг у 2007 р. - 18,5\% (рис. 4). Найбільший спад експорту товарів і послуг відзначався у 2009 р. $22,5 \%$ і 11,3\% відповідно. Частка світової торгівлі послугами у загальній світовій торгівлі товарами та послугами була максимальною у 2016 р. $33,2 \%$, у 2018 р. становила $31,8 \%$.

Загальний обсяг експорту послуг у світовій торгівлі збільшився з \$155 млрд у 1975 р. до $\$ 6,025$ трлн у 2019 р., тобто більш ніж у 35 разів. За останні двадцять років обсяги і експорту й імпорту послуг збільшилися у 3,6 раза, що пояснюється позитивною динамікою розвитку світового господарства, інтенсифікацією міжнародних економічних зв'язків, глобалізацією бізнесу та економічним пожвавленням у провідних країнахекспортерах послуг.

Домінуючі позиції на світовому ринку послуг збергіають розвинені країни (табл. 1). У 2000 р. на них припадало близько $75,3 \%$ світового експорту і 70,7\% світового імпорту послуг. За останні 18 років помітною стала тенденція до зменшення частки розвинених країн у світовому експорті та імпорті послуг $(67,9 \%$ і 59,4\% відповідно у 2018 р.) та збільшення частки країн, що розвива- ються (29,7\% і 37,8\% відповідно у 2018 р.). Частка країн із перехідною економікою у світовому експорті послуг у 2018 р. становила $2,4 \%$, а у світовому імпорті $-2,9 \%$.

У середині 1990-х років частка окремих регіонів у світовому експорті послуг була такою: Європи - 49\%, в Азії - 23\%, Північної Америки $18 \%$, Латинської Америки - 4\%, Африки - 2\%, інших регіонів $-4 \%$.

Аналіз сучасного стану світового ринку послуг засвідчує, що епіцентром світової торгівлі послугами у 2018 р. залишається Європа, на яку припадає \$2,83 трлн експорту та $\$ 2,46$ трлн імпорту послуг, що відповідно становить 48,4\% і 46,9\% у світових показниках (рис. 5, рис. 6.) Другу позицію у міжнародній торгівлі послугами займає Азія, яка у 2018 р. експортувала послуг на суму $\$ 1,70$ трлн (29\% світового експорту послуг), а імпортувала послуг на суму $\$ 1,98$ трлн $(35,3 \%$ світового імпорту послуг). Загалом Азія імпортує більше послуг, ніж експортує. Трійку лідерів за обсягами міжнародної торгівлі послугами замикає Північна Америка з експортом послуг $\$ 0,9229$ трлн та імпортом послуг \$0,6731 трлн, що становить $15,8 \%$ та $12,0 \%$ відповідно у світових показниках.

Такий стан кон'юнктури світового ринку послуг пов'язаний із зростанням процесів роботолізації, автомобілізації, урбанізації та переміщення жителів міських центрів до передмістя,

\section{Таблиця 1 - Динаміка експорту та імпорту послуг у країнах різного рівня економічного розвитку}

\begin{tabular}{|c|c|c|c|c|c|c|c|c|c|c|c|c|}
\hline \multirow[t]{2}{*}{ Показники } & \multicolumn{7}{|c|}{ Роки } & \multicolumn{5}{|c|}{$\begin{array}{l}\text { Частка у світовому } \\
\text { експорті/імпорті, \% }\end{array}$} \\
\hline & 2000 & 2005 & 2010 & 2015 & 2016 & 2017 & 2018 & 2000 & 2005 & 2010 & 2015 & 2018 \\
\hline $\begin{array}{l}\text { Світовий експорт послуг, } \\
\text { \$ трлн }\end{array}$ & 1,52 & 2,66 & 3,92 & 4,96 & 5,03 & 5,43 & 5,85 & 100 & 100 & 100 & 100 & 100 \\
\hline $\begin{array}{l}\text { в тому числі: } \\
\text { - розвинені країни }\end{array}$ & 1,15 & 1,99 & 2,73 & 3,39 & 3,46 & 3,72 & 3,97 & 75,3 & 73,3 & 69,9 & 68,3 & 67,9 \\
\hline - країни, що розвиваються & 0,35 & 0,61 & 1,09 & 1,47 & 1,47 & 1,59 & 1,74 & 23,1 & 24,5 & 27,8 & 29,6 & 29,7 \\
\hline $\begin{array}{l}\text { - країни з перехідною } \\
\text { економікою }\end{array}$ & 0,02 & 0,05 & 0,1 & 0,1 & 0,11 & 0,12 & 0,14 & 1,6 & 2,2 & 2,6 & 2,0 & 2,4 \\
\hline $\begin{array}{l}\text { Світовий імпорт послуг, \$ } \\
\text { трлн }\end{array}$ & 1,52 & 2,61 & 3,83 & 4,88 & 4,91 & 5,22 & 5,61 & 100 & 100 & 100 & 100 & 100 \\
\hline $\begin{array}{l}\text { в тому числі } \\
\text { - країни, що розвиваються }\end{array}$ & 0,42 & 0,74 & 1,32 & 86 & 1,83 & 1,96 & 2,12 & 27,4 & 28,3 & 34,5 & 38,1 & 37,8 \\
\hline $\begin{array}{l}\text { - країни з перехідною } \\
\text { економікою }\end{array}$ & 0,03 & 0,07 & 0,12 & 0,14 & 0,13 & 0,15 & 0,16 & 1,9 & 2,8 & 3,1 & 2,9 & 2,9 \\
\hline - розвинені країни & 1,08 & 1,8 & 2,39 & 2,88 & 2,95 & 3,11 & 3,33 & 70,7 & 68,9 & 62,4 & 59,0 & 59,4 \\
\hline \multicolumn{13}{|l|}{$\begin{array}{l}\text { Довідково: } \\
\text { Україна }\end{array}$} \\
\hline $\begin{array}{l}\text { Експорт послуг, } \\
\text { \$ млрд. }\end{array}$ & 3,66 & 6,44 & 11,94 & 9,74 & 9,87 & 10,71 & 11,64 & 0,24 & 0,24 & 0,30 & 0,19 & 0,19 \\
\hline $\begin{array}{l}\text { Імпорт послуг, } \\
\text { \$ млрд. }\end{array}$ & 1,15 & 2,94 & 5,42 & 5,52 & 5,33 & 5,48 & 6,31 & 0,08 & 0,12 & 0,14 & 0,11 & 0,11 \\
\hline
\end{tabular}

Джерело: побудовано і розраховано за даними [3; 12] 


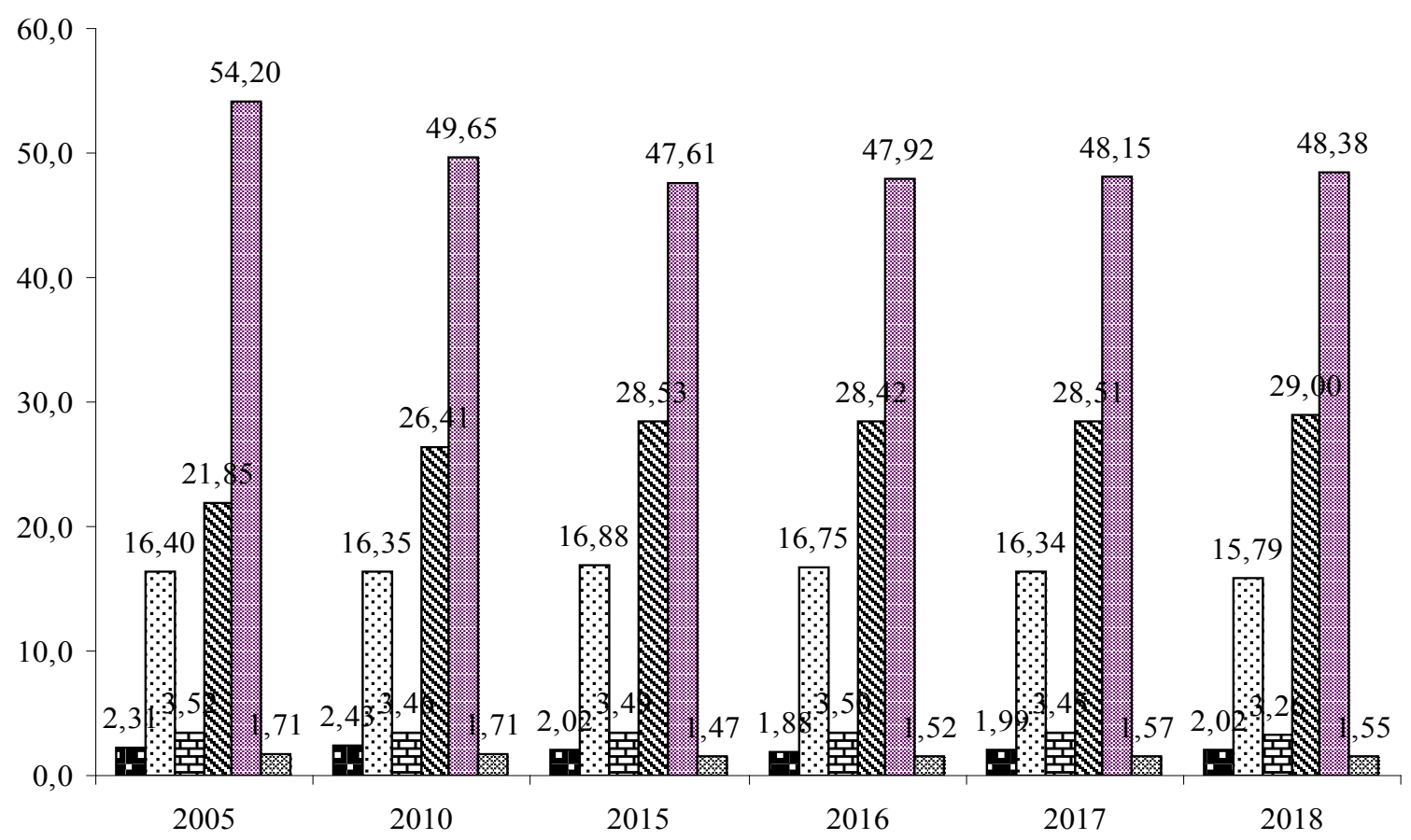

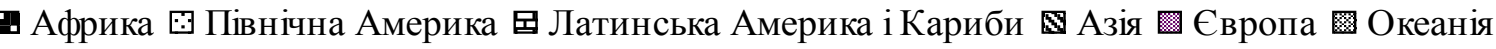

Рисунок 5 - Частка макрорегіонів у світовому експорті послуг в 2005-2018 рр., \% Джерело: побудовано і розраховано за даними [12]





Рисунок 6 - Частка макрорегіонів у світовому імпорті послуг в 2005-2018 рр., \% Джерело: побудовано і розраховано за даними [12] 




\section{Рисунок 7 - Річні темпи зростання торгівлі послугами в країнах різного рівня} економічного розвитку у 2018 р., \%

Джерело: побудовано і розраховано за даними [10; 12]

зростанням цінностей вільного часу, розвитком НТП, насамперед інформаційних технологій.

Країни з перехідною економікою та країни, що розвиваються в Азії та Океанії, продемонстрували значне збільшення експорту послуг (понад 10\%), що перевищує їхне зростання в імпорті (рис. 7). В Африці спостерігається значне збільшення імпорту $(11,9 \%)$ з одночасним повільним зрос-

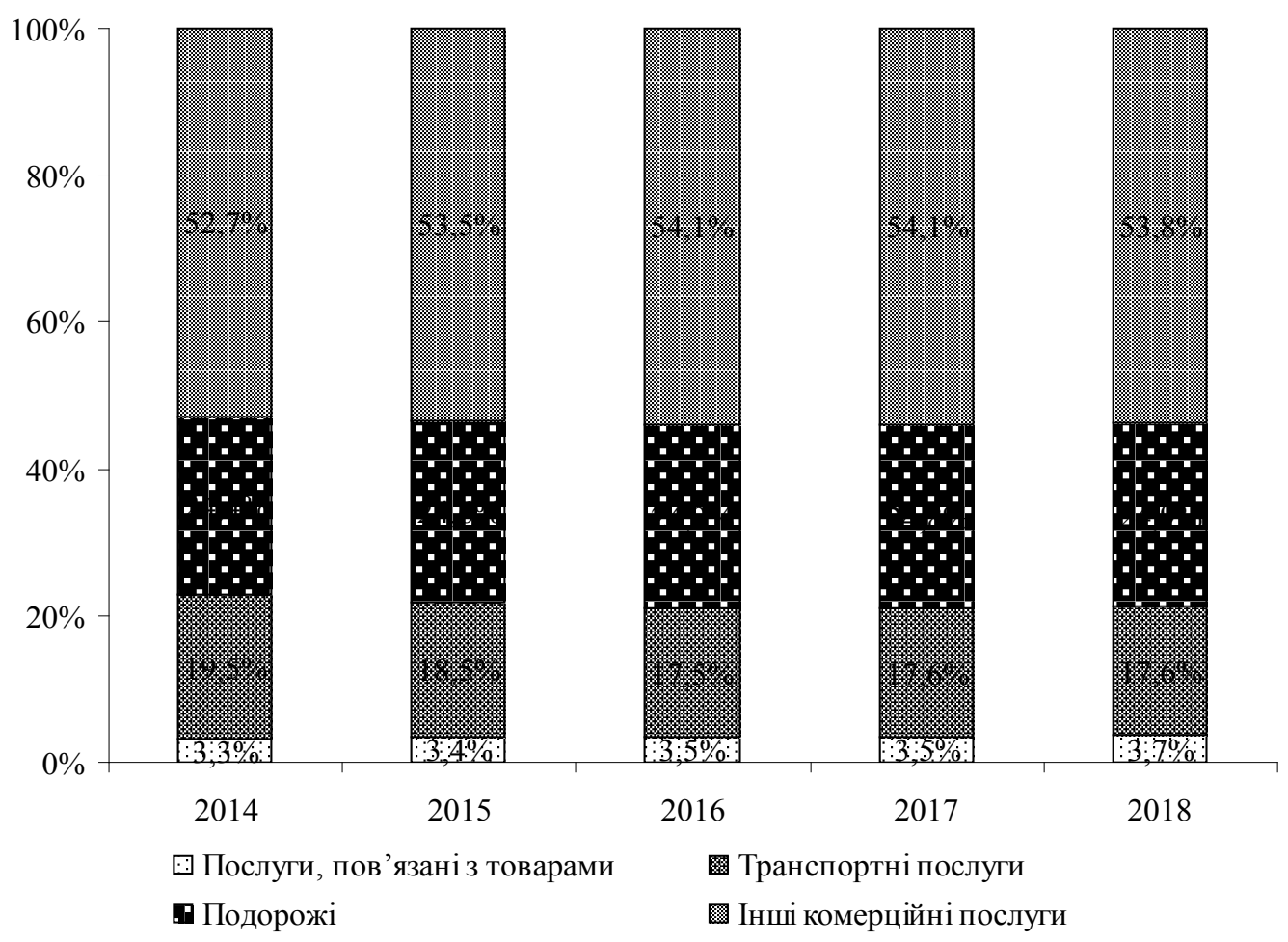

Рисунок 8 - Динаміка частки світового експорту основних категорій послуг у 2014-2018 pp.

Джерело: побудовано на основі [7] 
танням експорту. На американському континенті в економіках країн, що розвиваються, експорт та імпорт послуг зросли менш ніж на 2\%, а експорт та імпорт послуг в країнах із розвиненими економіками зростав приблизно однаковими темпами (у межах 7\%).

Найбільшим світовим експортером послуг у 2019 р. були США з показником \$824 млрд, що становить 13,7\% світового експорту послуг (табл. 2). До країн лідерів світового експорту послуг увійшли Велика Британія (6,8\%), Німеччина (5,5\%). Зростає частка десяти країн із найбільшим обсягом експорту послуг у світовому експорті послуг: якщо у 2012 р. цей показник становив 51,8\%, то у 2018 р. - 53,67\%. Частка України у світовому екс- порті послуг зменшилась упродовж 2010-2019 pр. iз $0,30 \%$ до $0,25 \%$.

Країни за найбільшим обсягом імпорту послуг - це США, Китай і Німеччина (табл. 3). Їхня загальна частка у світовому імпорті послуг становила 23,1\% у 2012 р., 26,5\% у 2016 р. та $25,7 \%$ у 2018 р. Частка десяти країн-лідерів у світовому імпорті послуг становила 48,5\% у 2012 р., $53,4 \%$ у 2016 р. і 52,8\% у 2018 р. Частка України в світовому імпорті послуг знизилася 3 0,14\% в 2010 р. до 0,11\% в 2018 р.

За результатами маркетингових досліджень можна висновувати, що позитивна динаміка міжнародної торгівлі послугами у 1995-2018 pр. супроводжувалася, по-перше, вираженою аси-

Таблиця 2 - Провідні експортери на світовому ринку послуг у 2017-2019 pp.

\begin{tabular}{|c|c|c|c|c|c|c|c|c|c|c|}
\hline \multirow[b]{2}{*}{ Країна } & \multirow[b]{2}{*}{ Рейтинг } & \multicolumn{3}{|c|}{ Обсяг, \$ млрд. } & \multicolumn{3}{|c|}{ Частка, \% } & \multicolumn{3}{|c|}{ Темп змін, \% } \\
\hline & & 2017 & 2018 & 2019 & 2017 & 2018 & 2019 & $\begin{array}{l}2017 / \\
2016\end{array}$ & $\begin{array}{l}2018 / \\
2017\end{array}$ & \begin{tabular}{|c|}
$2019 /$ \\
2018
\end{tabular} \\
\hline США & 1 & 762 & 808 & 824 & 14,5 & 13,9 & 13,7 & 3,8 & 4 & 2 \\
\hline Великобританія & 2 & 354 & 381 & 412 & 6,7 & 6,6 & 6,8 & 4,9 & 7 & 2 \\
\hline Німеччина & 3 & 296 & 337 & 331 & 5,6 & 5,8 & 5,5 & 7 & 7 & -2 \\
\hline Китай & 4 & 226 & 265 & 282 & 4,3 & 4,6 & 4,7 & 8,7 & 17 & 4 \\
\hline Франція & 5 & 249 & 287 & 280 & 4,7 & 5 & 4,6 & 5,5 & 5 & -5 \\
\hline Нідерланди & 6 & 216 & 241 & 262 & 4,1 & 4,2 & 4,3 & 15,6 & 11 & 6 \\
\hline Ірландія & 7 & 182 & 206 & 238 & 3,5 & 3,6 & 3,9 & 19,6 & 14 & 12 \\
\hline Індія & 8 & 179 & 206 & 214 & 3,4 & 3,5 & 3,5 & 11 & 11 & 5 \\
\hline Сінгапур & 9 & 165 & 184 & 205 & 3,1 & 3,2 & 3,4 & 4,3 & 7 & 1 \\
\hline Японія & 10 & 180 & 187 & 201 & 3,4 & 3,2 & 3,3 & 6,7 & 3 & 6 \\
\hline Іспанія & 11 & 137 & 149 & 157 & 2,6 & 2,6 & 2,6 & 8 & 8 & 1 \\
\hline Швейцарія & 12 & 122 & 122 & 122 & 2,3 & 2,1 & 2 & 4 & 1 & -3 \\
\hline Італія & 13 & 110 & 120 & 121 & 2,1 & 2,1 & 2 & 10,4 & 8 & -1 \\
\hline Бельгія & 14 & 113 & 121 & 119 & 2,2 & 2,1 & 2 & 1,8 & 3 & -2 \\
\hline Люксембург & 15 & 102 & 113 & 112 & 1,9 & 1,9 & 1,9 & 6,5 & 10 & -2 \\
\hline Республіка Корея & 16 & 86 & 98 & 107 & 1,6 & 1,7 & 1,8 & -8 & 10 & 4 \\
\hline Гонконг, Китай & 17 & 104 & 114 & 101 & 2 & 2 & 1,7 & 5,3 & 9 & -10 \\
\hline Канада & 18 & 86 & 92 & 99 & 1,6 & 1,6 & 1,6 & 5,8 & 6 & 1 \\
\hline Тайланд & 19 & 75 & 84 & 81 & 1,4 & 1,4 & 1,4 & 11,7 & 11 & 6 \\
\hline Швеція & 20 & 73 & 73 & 76 & 1,4 & 1,3 & 1,3 & 2,4 & -1 & 2 \\
\hline Данія & 21 & 64 & 70 & 74 & 1,2 & 1,2 & 1,2 & 7 & 4 & -5 \\
\hline Австрія & 22 & 64 & 75 & 73 & 1,2 & 1,3 & 1,2 & 5 & 14 & -1 \\
\hline OAE & 23 & 70 & 71 & 72 & 1,3 & 1,2 & 1,2 & 7,5 & 2 & 2 \\
\hline Польща & 24 & 57 & 69 & 72 & 1,1 & 1,2 & 1,2 & 14,8 & 17 & 4 \\
\hline Австралія & 25 & 65 & 69 & 70 & 1,2 & 1,2 & 1,2 & 13,5 & 7 & 1 \\
\hline Туреччина & 26 & 44 & 47 & 64 & 0,8 & 0,8 & 1,1 & 17,4 & 9 & 10 \\
\hline Росія & 27 & 58 & 64 & 64 & 1,1 & 1,1 & 1,1 & 15,9 & 12 & 0 \\
\hline Ізраїль & 28 & 44 & 50 & 55 & 0,8 & 0,9 & 0,9 & 11,1 & 12 & 11 \\
\hline Тайпей, Китай & 29 & 45 & 50 & 51 & 0,9 & 0,9 & 0,9 & 9 & 12 & 3 \\
\hline Норвегія & 30 & 41 & 44 & 45 & 0,8 & 0,8 & 0,7 & $-2,2$ & 9,6 & 2 \\
\hline Разом по 30 краӥнах & & 4365 & 4797 & 4983 & 83,1 & 83 & 82,7 & - & - & - \\
\hline \multicolumn{11}{|l|}{ Довідково: } \\
\hline Україна & & 10,7 & 11,6 & 15,2 & 0,20 & 0,20 & 0,25 & 8,58 & 8,62 & 30,93 \\
\hline Разом у світі & & 5252 & 5800 & 6025 & 100 & 100 & 100 & 7,4 & 8 & 2 \\
\hline
\end{tabular}

Джерело: побудовано і розраховано за даними [3; 17;18] 
метричністю географічної спрямованості експорту та імпорту послуг на користь промислово розвинених країн; по-друге, високою концентрацією світового експорту та імпорту послуг у небагатьох країнах світу; по-третє, збільшенням частки країн, що розвиваються, в міжнародній торгівлі послугами.

Маркетинговими дослідженнями встановлено, що структура світового ринку послуг також зазнала суттєвих змін. Якщо на початку 1980-х рр. перше місце в експорті послуг займали транспортні, то тепер їхня частка скоротилася до 17\%. Частка туристичних послуг залишається відносно стабільною, у межах $25 \%$, а от частка інших послуг зростає швидше, і у структурі світового експорту послуг саме вони набувають визначального значення (рис. 8).

На глобальному рівні у 2017-2018 рр. телекомунікаційні, комп'ютерні та інформаційні послуги були категорією, за якою світова торгівля послугами зростала найшвидше $(14,7 \%) ;$ i це приблизно вдвічі більший показник, ніж зростання у категоріях транспортних, туристичних, страхових, фінансових, інтелектуальної власності та інших бізнес-послуг. Експорт інших видів послуг - головним чином, пов'язаних із товарами, будівництвом, побутовими, культурними та рекреаційними послугами та певними державними товарами і послугами - збільшився на 9,1\% між 2017 та 2018 pp.

Таблиця 3 - Провідні імпортери на світовому ринку послуг у 2017-2019 рр.

\begin{tabular}{|c|c|c|c|c|c|c|c|c|c|c|}
\hline \multirow[b]{2}{*}{ Країна } & \multirow[b]{2}{*}{ Рейтинг } & \multicolumn{3}{|c|}{ Обсяг, \$ млрд. } & \multicolumn{3}{|c|}{ Частка, \% } & \multicolumn{3}{|c|}{ Темп змін, \% } \\
\hline & & 2017 & 2018 & 2019 & 2017 & 2018 & 2019 & $\begin{array}{l}2017 / \\
2016 \\
\end{array}$ & $\begin{array}{l}\text { 2018/ } \\
2017\end{array}$ & $\begin{array}{c}2019 / \\
2018 \\
\end{array}$ \\
\hline США & 1 & 516 & 536 & 571 & 10,2 & 9,7 & 9,9 & 6,8 & 3 & 5 \\
\hline Китай & 2 & 464 & 521 & 497 & 9,2 & 9,4 & 8,6 & 3,3 & 12 & -5 \\
\hline Німеччина & 3 & 319 & 364 & 360 & 6,3 & 6,6 & 6,3 & 5,2 & 6 & -1 \\
\hline Ірландія & 4 & 196 & 219 & 320 & 3,9 & 4 & 5,6 & $-3,4$ & 9 & 46 \\
\hline Великобританія & 5 & 218 & 228 & 278 & 4,3 & 4,1 & 4,8 & 4,3 & 10 & 8 \\
\hline Франція & 6 & 244 & 255 & 256 & 4,8 & 4,6 & 4,5 & 3,4 & 4 & -4 \\
\hline Нідерланди & 7 & 211 & 230 & 246 & 4,2 & 4,2 & 4,3 & 14,7 & 11 & 1 \\
\hline Японія & 8 & 189 & 198 & 202 & 3,4 & 3,6 & 3,5 & 3,5 & 4 & 2 \\
\hline Сінгапур & 9 & 171 & 187 & 199 & 3,4 & 3,4 & 3,5 & 5,2 & 3 & -1 \\
\hline Індія & 10 & 150 & 175 & 178 & 3 & 3,2 & 3,1 & 13,1 & 14 & 2 \\
\hline Республіка Корея & 11 & 120 & 127 & 129 & 2,4 & 2,3 & 2,2 & 8,1 & 2 & -2 \\
\hline Італія & 12 & 111 & 121 & 122 & 2,2 & 2,2 & 2,1 & 8,8 & 6 & -1 \\
\hline Бельгія & 13 & 116 & 127 & 120 & 2,3 & 2,3 & 2,1 & 7,3 & 10 & -3 \\
\hline Канада & 14 & 105 & 112 & 114 & 2,1 & 2 & 2 & 6,5 & 5 & 0 \\
\hline Швейцарія & 15 & 104 & 103 & 104 & 2,1 & 1,9 & 1,8 & 4,9 & 0 & -2 \\
\hline Росія & 16 & 87 & 94 & 98 & 1,7 & 1,7 & 1,7 & 18,8 & 7 & 6 \\
\hline Люксембург & 17 & 75 & 86 & 86 & 1,5 & 1,6 & 1,5 & 4,5 & 10 & -1 \\
\hline Іспанія & 18 & 74 & 88 & 86 & 1,5 & 1,6 & 1,5 & 6,2 & 16 & 5 \\
\hline Гонконг, Китай & 19 & 77 & 81 & 79 & 1,5 & 1,5 & 1,4 & 3,7 & 5 & -3 \\
\hline Швеція & 20 & 68 & 68 & 73 & 1,3 & 1,2 & 1,3 & 11,5 & 1 & 1 \\
\hline OAE & 21 & 84 & 71 & 7 & 1,7 & 1,3 & 1,3 & 1,9 & 1 & 2 \\
\hline Данія & 22 & 62 & 68 & 71 & 1,2 & 1,2 & 1,2 & 6 & 10 & 0 \\
\hline Австралія & 23 & 66 & 72 & 71 & 1,3 & 1,3 & 1,2 & 8,5 & 6 & -2 \\
\hline Бразилія & 24 & 66 & 66 & 67 & 1,3 & 1,2 & 1,2 & 7,9 & -1 & -3 \\
\hline Австрія & 25 & 53 & 62 & 63 & 1,1 & 1,1 & 1,1 & 9,3 & 13 & 1 \\
\hline Тайланд & 26 & 46 & 55 & 58 & 0,9 & 1 & 1 & 5,5 & 19 & 6 \\
\hline Тайпей, Китай & 27 & 53 & 57 & 56 & 1 & 1 & 1 & 3,4 & 6 & 0 \\
\hline Саудівська Аравія & 28 & 53 & 51 & 55 & 1 & 0,9 & 1 & 5,6 & -6 & -1 \\
\hline Норвегія & 29 & 49 & 53 & 53 & 1,0 & 1,0 & 0,9 & 3,1 & 5,9 & 0 \\
\hline Польща & 30 & 38 & 44 & 45 & 0,7 & 0,8 & 0,8 & 12,2 & 13,8 & 3 \\
\hline Разом по 30 краӥнах & & 4189 & 4518 & 4729 & 82,6 & 81,8 & 82,3 & - & - & - \\
\hline Довідково: & & & & & & & & & & \\
\hline Україна & & 5,48 & 6,31 & 6,53 & 0,11 & 0,11 & 0,11 & 2,8 & 15,2 & 3,5 \\
\hline Разом у світі & & 5072 & 5510 & 5745 & 100 & 100 & 100 & 6,5 & 7 & 2 \\
\hline
\end{tabular}

Джерело: побудовано і розраховано за даними [3; 17;18] 


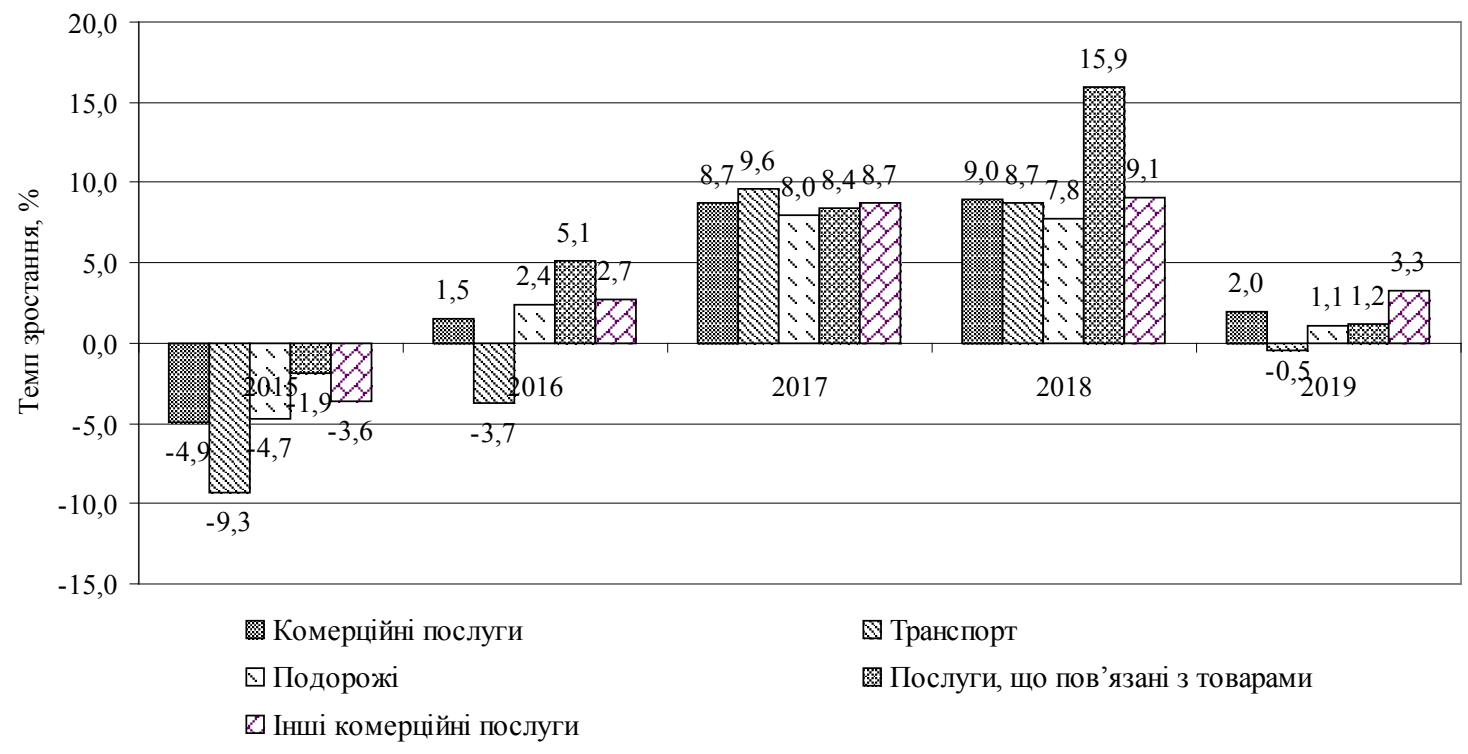

Рисунок 9 - Динаміка темпів зростання експорту послуг за категоріями послуг y 2015-2019 pp.

Джерело: побудовано на основі [17; 18; 19]

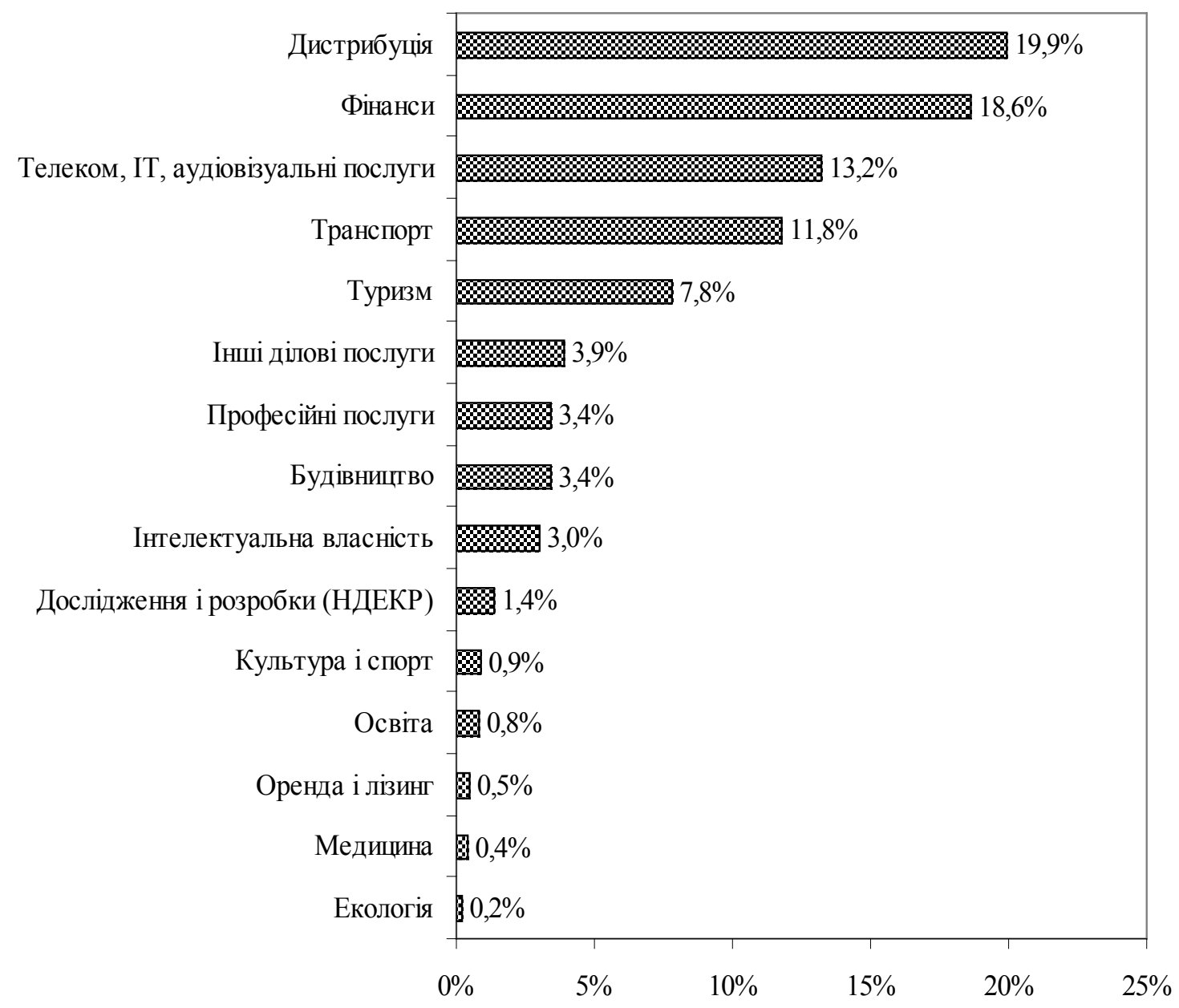

Рисунок 10 - Частка окремих видів послуг у світовій торгівлі послугами у 2017 р. Джерело: побудовано на основі [15; 18$]$ 
Незважаючи на те, що послуги не мають такої тарифної політики, як товари, світова торгівля послугами різко сповільнилася у вартісному вираженні у 2019 р. після зафіксованого значного зростання у попередні два роки. Наочно це ми бачимо 3 рис. 9, де показано динаміку темпів зростання експорту основних категорій послуг. Категорія «Інші комерційні послуги» мала найбільший приріст із збільшенням на 3\% у 2019 р., далі йшли подорожі та послуги, пов'язані з товарами (на 1\% кожна категорія). Зниження транспортних послуг на $0,5 \%$ відбулося через зменшення обсягів торгівлі товарами внаслідок торговельних суперечок між США та Китаєм [17].

У структурі світового ринку послуг домінують дистрибуція і фінанси (рис. 10), разом вони займають майже 40\% обсягу міжднародної торгівлі послугами. Показово, що світова торгівля фінансовими послугами досягла $\$ 2,5$ трлн у 2017 р. Трете місце в міжнародній торгівлі послугами займають телекомунікації, далі йдуть транспорт і туризм. Торгівля послугами в сфері телекомунікацій та інформаційних технологій більш ніж подвоїлася у 2005-2017 pp. Варто зазначити, що, хоча торгівля послугами в сфері охорони здоров'я та наукових досліджень і розробок поки поступається переліченим категоріям-лідерам за обсягом, вона стрімко зростає, збільшуючись на 10\% щорічно.

У 2018 р. дванадцять основних категорій послуг сукупно становили $98,8 \%$ від загальної суми їх експорту \$5,302 трлн (табл. 4). Залишок припадає на державні товари та послуги.

Не беручи до уваги інші види послуг, бачимо, що швидше зростає експорт послуг 3 обслуговування та ремонту $(35,4 \%)$, телекомунікації, комп'ютерні та інформаційні послуги $(28,6 \%)$, використання інтелектуальної власності
$(17,1 \%)$, послуги, пов'язані з подорожами (12,5\%). Спадні показники експорту послуг за п'ятирічний період були у таких категоріях послуг, як державні товари та послуги $(-5,3 \%)$, будівництво $(-3,5 \%)$, страхові та пенсійні послуги $(-1,8 \%)$.

У період 2013-2018 pр. експорт усіх категорій послуг, окрім транспорту, зафіксував достатне зростання у більшості регіонів світу. Експорт телекомунікаційних, комп'ютерних та інформаційних послуг щорічно збільшувався в Азії на 9,5\%, у Латинській Америці та Карибському басейні, Європі та Океанії між 6 і 7\%, а в Африці застоювався. Африка, своєю чергою, разом 3 Азією демонструвала порівняно значне збільшення експорту страхових, фінансових, інтелектуальної власності та інших бізнес-послуг, демонструючи щорічні темпи зростання від 6 до 7\%. Це особливо примітно, враховуючи невеликий розмір цього сектора в Африці, як стосовно світового ринку, так і до загального експорту послуг 3 Африки. Експорт подорожей збільшився на всіх континентах - особливо в Латинській Америці та Карибському басейні, де зафіксовано щорічне збільшення на 6,3\% [11].

У короткостроковій перспективі міжнародна торгівля послугами буде визначатися такими чинниками, як: зростання впливу цифрових технологій, демографічні зміни, наслідки зміни клімату. Водночас вплив глобальних тенденцій на світову торгівлю загалом створює передумови для появи нових видів послуг, змінює попит на послуги i відкриває нові ринки надання послуг, зокрема, у сфері охорони здоров'я і охорони навколишнього середовища [2; 19].

Згідно досліджень СОТ, до 2040 року частка сектору послуг у світовій торгівлі досягне $50 \%$. Якщо країни, що розвиваються зможуть

Таблиця 4 - Структура світового експорту послуг у 2018 р.

\begin{tabular}{|c|l|l|l|l|}
\hline \multicolumn{1}{|c|}{ Вид послуг } & $\begin{array}{c}\text { Обсяг світового } \\
\text { експорту послуг, } \\
\text { млрд. } \mathbf{~}\end{array}$ & $\begin{array}{c}\text { Частка, } \\
\text { \% }\end{array}$ & $\begin{array}{c}\text { Tемп змін } \\
\text { порівняно } \\
\mathbf{3} \mathbf{2 0 1 4} \text { р., \% }\end{array}$ \\
\hline 1 & Подорожі & 1405 & 24,72 & $+12,5$ \\
\hline 2 & Бізнес-послуги & 1222 & 21,50 & $+9,7$ \\
\hline 3 & Транспорт & 996,8 & 17,54 & $+1,2$ \\
\hline 4 & Телекомунікаційні / комп'ютерні / інформаційні & 596,4 & 10,49 & $+28,6$ \\
\hline 5 & Фінансові & 480,9 & 8,46 & $+5,3$ \\
\hline 6 & Послуги щодо інтелектуальної власності & 400,9 & 7,05 & $+17,1$ \\
\hline 7 & Страхові / пенсійні & 136 & 2,39 & $-1,8$ \\
\hline 8 & Виробничі & 106,6 & 1,88 & $+9,7$ \\
\hline 9 & Будівництво & 104,1 & 1,83 & $-3,1$ \\
\hline 10 & Послуги з обслуговування / ремонту & 95,1 & 1,67 & $+35,4$ \\
\hline 11 & Державні товари, послуги & 69,4 & 1,22 & $-5,3$ \\
\hline 12 & Особисті, культурні, рекреаційні & 47,3 & 0,83 & $+0,8$ \\
\hline 13 & Інші види & 22,4 & 0,39 & $+177,7$ \\
\hline
\end{tabular}

Джерело: побудовано на основі [14] 
впровадити цифрові технології, їх частка в торгівлі послугами в світі може збільшитися приблизно на $15 \%[17 ; 18]$. Незважаючи на реформи, проведені в більшості країн за останні десятиліття, у сфері торгівлі послугами продовжують діяти суттєві обмеження і бар'єри. Проведення необхідних реформ щодо лібералізації міжнародної торгівлі послугами, укладення нових торговельних угод виявилося складним завданням, яке все ж потребує вирішення.

Маркетингові дослідження засвідчили, що в Україні спостерігається стала тенденція розвитку сфери послуг, темпи зростання якої випереджають динаміку ВВП. За даними Держстату, експорт послуг у 2019 р. становив $\$ 15237,5$ млн, збільшившись на $30,9 \%$, або на $\$ 3596,9$ млн порівняно 32018 р. Імпорт послуг становив $\$ 6527,9$ млн, збільшившись на $3,5 \%$, або на $\$ 220,8$ млн порівняно з 2018 р. (табл. 5). У 2019 р. сальдо зовнішньої торгівлі послугами в Україні становило $\$ 8709,6$ млн.

Структуру експорту послуг майже на $2 / 3$ формують транспортні (\$9036,4 млн у 2019 р.), близько $65 \%$ яких становлять послуги трубопровідного транспорту. Проте значним є потенціал інших видів транспортних послуг, на які чомусь невиправдано мало звертається уваги під час формування економічної політики. Теперішній обсяг експорту морського транспорту (\$580,7 млн) та повітряного (\$1409,6 млн) аж ніяк не відповідає геополітичному становищу України. Маркетингові дослідження підтверджують, що структура зовнішньої торгівлі послугами значною мірою визначається економічною і політичною ситуацією в Україні. В експорті послуг частка транспортних послуг скоротилася через зниження товарного експорту, водночас зросла частка послуг із переробки матеріальних ресурсів. Сформувалася тенденція щодо зростання експорту телекомунікаційних, комп'ютерних та інших інформаційних послуг, які в 2018 р. зайняли 18,2\% загального експорту послуг. Невиправдано низькою є частка експорту туристичних послуг у межах $2 \%$, тоді як частка їхнього імпорту збільшується швидкими темпами і досягла майже $20 \%$. Частка транспортних послуг в їхньому імпорті зросла до $23,1 \%$ у 2019 р. порівняно з $21 \%$ у 2015 р. Попри те, що експорт послуг демонструє зростаючу тенденцію, можливості України у підвищенні ролі сфери послуг у формуванні нової економіки далеко не

Таблиця 5 - Динаміка структури експорту та імпорту послуг України у 2010-2019 рр.

\begin{tabular}{|c|c|c|c|c|c|c|c|c|c|c|c|c|}
\hline \multirow[t]{2}{*}{ Показник } & \multicolumn{6}{|c|}{ Обсяг, млрд. \$ } & \multicolumn{6}{|c|}{$\begin{array}{c}\text { Частка в українському } \\
\text { експорті/імпорті, \% }\end{array}$} \\
\hline & 2010 & 2015 & 2016 & 2017 & 2018 & 2019 & 2010 & 2015 & 2016 & 2017 & 2018 & 2019 \\
\hline Експорт послуг, всього & 12,32 & 9,74 & 9,87 & 10,71 & 11,64 & 15,24 & 100,0 & 100,0 & 100,0 & 100,0 & 100,0 & 100,0 \\
\hline Транспортні послуги & 7,84 & 5,26 & 30 & 5,86 & 5,85 & 9,04 & 63,6 & 54,1 & 53,7 & 54,7 & 50,3 & 59,3 \\
\hline $\begin{array}{l}\text { у у сфері } \\
\text { унікації, комп’ютерні } \\
\text { маційні послуги }\end{array}$ & 0,68 & 1,59 & 1,64 & 1,76 & 2,12 & 2,43 & 5,5 & 16,3 & 16,7 & 16,4 & 18,2 & 16,0 \\
\hline & 1,05 & 1,08 & 1,13 & 1,42 & 1,70 & 1,63 & 8,5 & 11,1 & 11,4 & 13,3 & 14,6 & 10,7 \\
\hline Ділові послу & 1,15 & 0,82 & 79 & 92 & 06 & 1,20 & 9,3 & 8,4 & 8,0 & 8,6 & 9,1 & 7,9 \\
\hline &, 38 & 0,20 & ,21 & 24 & 0,30 & 0,32 & 3,1 & 2,1 & 2,1 & 2,3 & 2,6 & 2,1 \\
\hline Інші послуги & 1,23 & 0,79 & 0,80 & 0,51 & 0,61 & 0,61 & 10,0 & 8,1 & 8,1 & 4,7 & 5,3 & 4,0 \\
\hline Імпорт послуг, всього & 5,47 & 5,52 & 5,33 & 5,48 & 6,31 & 6,53 & 100 & 100 & 100 & 100 & 100 & 100 \\
\hline Транспортні п & 1,18 & 1,15 & 0,99 & 1,21 & 1,46 & 1,51 & 21,6 & 20,9 & 18,6 & 22,2 & 23,2 & 23,1 \\
\hline Ділові послуги & 1,04 & 0,72 & 0,81 & 0,83 & 1,39 & 1,29 & 19,1 & 13,0 & 15,3 & 15,1 & 22,0 & 19,8 \\
\hline По & 0,35 & 0,60 & 0,6 & 80 & 99 & 1,28 & 6, & 10,8 & 11,3 & 14,5 & 15,7 & 19,7 \\
\hline Держ & 53 & 1,06 & & 06 & 79 & 0,73 & & 19,1 & 25,0 & 19,3 & 12,5 & 11,1 \\
\hline $\begin{array}{l}\text { Роялті та інш } \\
\text { пов'язані з в } \\
\text { інтелектуаль }\end{array}$ & 0,44 & 0,30 & בי, & 0,41 & 49 & 0,54 & 0 & 5,5 & 6,1 & 7,4 & 7,8 & 8,3 \\
\hline $\begin{array}{l}\text { Послуги у сфері } \\
\text { телекомунікації, комп'ютер } \\
\text { та інформаційні послуги }\end{array}$ & 0,30 & 0,55 & 0,42 & 0,42 & 0,47 & 0,50 & 5,5 & 9,9 & 7,9 & 7,7 & 7,5 & 7,6 \\
\hline $\begin{array}{l}\text { Послуги, пов'язані } \\
3 \text { фінансовою діяльністю }\end{array}$ & 1,09 & 0,87 & 0,56 & 0,42 & 0,48 & 0,46 & 19,9 & 15,8 & 10,5 & 7,8 & 7,6 & 7,1 \\
\hline Інші послуги & 0,55 & 0,27 & 0,28 & 0,33 & 0,24 & 0,22 & 10,0 & 4,9 & 5,3 & 6,0 & 3,7 & 3,3 \\
\hline
\end{tabular}

Джерело: розраховано та побудовано за даними [3] 
вичерпані. Тож посилення експортної орієнтації ринку послуг повинно стати одним із головних чинників модернізації структури економіки.

Результати маркетингових досліджень переконують, що тренд світової торгівлі послугами різко зміниться, починаючи 32020 р. Очікується, що світова торгівля зменшиться на $13 \%$ у 2020 р., оскільки пандемія COVID-19 порушує нормальну економічну активність та життедіяльність в усьому світі. У розпал фінансової кризи в 2009 р. торгівля знизилася на 12,5\% [6]. Звернімо увагу, що сучасна економічна криза, посилена пандемією COVID-19, доволі часто експертами порівнюється зі світовою фінансовою кризою 2008-2009 рр. Дійсно, ці кризи в деяких аспектах схожі, але в основному дуже різні. Як і в 2008-2009 pр., уряди знову втручаються в грошово-кредитну та фіскальну політику для протидії спаду та надання тимчасової підтримки доходів бізнесу та домогосподарств. Але обмеження на переміщення та соціальне дистанціювання для уповільнення розповсюдження захворювання означають, що пропозиція робочої сили, транспорт та подорожі сьогодні є найбільш уразливими, чого не було під час фінансової кризи. Цілі сектори національних економік закриті, включаючи заклади готельного, ресторанного господарства, роздрібну торгівлю непродовольчими товарами, туризм та значну частину виробництва.

Згідно з оптимістичним прогнозом СОТ, відновлення світової економіки повинно бути досить сильним, щоб до 2021 р. повернути її динаміку до тренду, який спостерігався до пандемії. Це залежатиме від тривалості COVID-19 та ефективності відповідних економічних і політичних заходів. Песимістичний прогноз передбачає лише часткове відновлення після спаду [4; 6].

Зростання обмежень на пересування людей та ізоляція в Європі і Північній Америці сильно вдаряють по сектору послуг, особливо в галузях, пов'язаних із фізичною взаємодією, таких як роздрібна торгівля, індустрія дозвілля, готельний і ресторанний бізнес, розважальні та транспортні послуги. Частка цих послуг охоплює понад чверть усіх робочих місць в цих макрорегіонах. Як ми зазначали раніше, експорт послуг у 2019 р. становив \$6,03 трлн, але COVID-19 найбільш негативно вплине на міжнародну торгівлю послугами через встановлення транспортних та туристичних обмежень та закриття багатьох закладів роздрібної торгівлі та гостинності. Хоча послуги не включаються до прогнозу торгівлі товарами СОТ, але більшість торгівлі товарами була б неможливою без відповідних послуг, насамперед транспортних. На відміну від товарів, не існує запасів послуг, які можна було б складувати для реалізації в пізні- шому періоді. Це означає, що зниження торгівлі послугами під час пандемії може бути незворотнім. Послуги також взаємопов'язані, наприклад, усі види транспорту дають змогу створювати екосистему інших ділових, освітніх, культурних, спортивних та рекреаційних заходів. Однак деякі послуги розвиваються під час кризи. Це стосується послуг інформаційних технологій, попит на які збільшується, оскільки компанії намагаються дати можливість працівникам працювати дома, люди більше спілкуються віддалено.

Висновки. В умовах становлення і розвитку постіндустріального суспільства сфера послуг набуває пріоритетного значення. 3 розвитком сфери послуг і насамперед галузей, що сприяють формуванню інформаційної економіки, пов'язують перспективи подальшого розвитку суспільства. Багато країн, які володіють достатніми науково-технологічними та сировинними ресурсами, необхідними для масштабних індустріальних проривів, забезпечують сьогодні зростання економіки саме завдяки інноваційному розвитку сфери послуг.

Торгівля послугами сприяє підвищенню добробуту суспільства, ефективнішому розподілу суспільних благ, розширенню спектру пропонованих послуг. Підвищення конкурентоспроможності підприємств у сфері послуг також є суттєвим для соціально-економічного розвитку країн. Зростання експорту послуг сприяє збільшенню зайнятості населення в багатьох країнах світу та подоланню соціальної, економічної та гендерної нерівності.

3 проведеного нами дослідження чітко можна констатувати, що частка торгівлі послугами у світовій торгівлі зростала швидше, ніж торгівля товарами. На фінансові послуги припадає п'ята частина від загального обсягу міжнародної торгівлі послугами. Частка послуг у сфері освіти, охорони здоров'я та охорони навколишнього середовища продовжувала збільшуватися. Частка послуг 3 доданою вартістю складає майже половину у загальних обсягах міжнародної торгівлі товарами і послугами. У більшості країн світу частка послуг в загальному обсязі експорту товарів i послуг постійно зростала. Політика щодо розвитку експорту послуг є важливою для всіх країн, позаяк сприяє покращанню структури зовнішньої торгівлі, підвищенню іiї ефективності, зростанню зайнятості населення. Це вимагає поглиблення співпраці між країнами і зниження бар'єрів у взаємній торгівлі найперспективнішими і швидко зростаючими видами послуг.

Врахування наслідків пандемії COVID-19 та сучасної глобальної економічної кризи для кон'юнктури світового ринку послуг є важливим завданням, що потребує подальших досліджень. 


\section{Список використаних джерел:}

1. Вовчанська О.М. Особливості функціонування та розвитку світового ринку послуг в структурі сучасної економіки / О.М. Вовчанська // Науковий вісник Херсонського державного університету. Серія «Економічні науки». Вип. 9-1. Частина 3. - Херсон, 2014. - С. 22-29. URL: http://www.ej.kherson.ua/journal/economic_09-1/economic_09-1_3. pdf\#page=22 (дата звернення: 05.05.2020).

2. ВТО опубликовала доклад по международной торговле услугами. URL: https://globalcentre.hse.ru/news/331611692. html (дата звернення: 05.05.2020).

3. Державна служба статистики України : офіційний вебсайт Державної служби статистики України. URL: http://ukrstat.gov.ua/ (дата звернення: 05.05.2020)

4. Епідемія коронавірусу: СОТ прогнозує уповільнення зростання світової торгівлі послугами в I кварталі 2020 року. URL: https://www.unn.com.ua/uk/news/1857221-epidemiya-koronavirusu-sot-prognozuye-upovilnennya-zrostannyasvitovoyi-torgivli-poslugami-v-i-kvartali-2020-roku (дата звернення: 05.05.2020).

5. Зачем развивать экспорт услуг. URL: https://www.vedomosti.ru/opinion/columns/2019/09/30/812490-zachem-razvivateksport (дата звернення: 05.05.2020)

6. Coronavirus could reduce world trade by up to a third, according to the WTO. URL: https://www.weforum.org/ agenda/2020/04/wto-financial-crisis-coronavirus-covid19-recession-trade-global/ (дата звернення: 05.05.2020).

7. Share of commercial services exports worldwide 2014 to 2018, by category. URL: https://www.statista.com/ statistics/649834/share-of-commercial-service-categories-in-world-export-trade/ (дата звернення: 05.05.2020).

8. The International Trade in Services. URL: https://www.rba.gov.au/publications/bulletin/2019/mar/the-international-tradein-services.html (дата звернення: 05.05.2020).

9. The services powerhouse: Increasingly vital to world economic growth. URL: https:/www2.deloitte.com/us/en/insights/ economy/issues-by-the-numbers/trade-in-services-economy-growth.html (дата звернення: 05.05.2020).

10. UNCTAD Handbook of Statistics 2019. Total trade in services. URL: https://stats.unctad.org/handbook/Services/Total. html (дата звернення: 05.05.2020).

11. UNCTAD Handbook of Statistics 2019. Trade in services by category . URL: https://stats.unctad.org/handbook/Services/ ByCategory.html (дата звернення: 05.05.2020).

12. UNCTADstat. Data Center. URL: https://unctadstat.unctad.org/wds/ReportFolders/reportFolders.aspx?sCS_ ChosenLang=en (дата звернення: 05.05.2020).

13. World Bank national accounts data, OECD national accounts data files, 2017-2019. URL: https://data.worldbank.org/ indicator/. (дата звернення: 05.05.2020).

14. World's Top Export Services. URL: http://www.worldstopexports.com/worlds-top-export-services/ (дата звернення: 05.05.2020).

15. WTO Data Portal (2020). URL: https://timeseries.wto.org/ (Accessed 05 May 2020).

16. WTO. Statistics on trade in commercial services. URL: https://www.wto.org/english/res_e/statis_e/tradeserv_stat_e.htm (дата звернення: 05.05.2020).

17. WTO. Trade set to plunge as COVID-19 pandemic upends global economy. URL: https://www.wto.org/english/news e/ pres20_e/pr855_e.htm (дата звернення: 05.05.2020).

18.WTO. World Trade Report 2019 “The Future of Services Trade”. URL: https://www.wto.org/english/res_e/publications_e/ wtr19_e.htm (дата звернення: 05.05.2020).

19. WTO. World Trade Statistical Review 2019. URL: https://www.wto.org/english/res_e/statis_e/wts2019_e/wts2019_e. pdf (дата звернення: 05.05.2020).

\section{References:}

1. Vovchanska O.M. "Osoblyvosti funktsionuvannia ta rozvytku svitovoho rynku posluh v strukturi suchasnoi ekonomiky" [The feautures of functioning and development of world market of services within the structure of modern economy]. Naukovyj visnyk Khersons'koho derzhavnoho universytetu. Seriia «Ekonomichni nauky». Vyp. 9-1. 2014. S. 22-29. [Online], available at: http://www.ej.kherson.ua/journal/economic_09-1/economic_09-1_3.pdf\#page=22 (accessed 05 May 2020).

2. Globalcentre. Competence Centre for Cooperation with International Organisations (2020), "VTO opublikovala doklad po mezhdunarodnoj torgovle uslugami”, available at: https://globalcentre.hse.ru/news/331611692.html (accessed 05 May 2020 ).

3. The official site of State Statistics Service of Ukraine (2020), available at: http://ukrstat.gov.ua/ (accessed 05 May 2020).

4. UNN (2020), "Epidemiia koronavirusu: SOT prohnozuie upovil'nennia zrostannia svitovoi torhivli posluhamy v I kvartali 2020 roku", available at: https://www.unn.com.ua/uk/news/1857221-epidemiya-koronavirusu-sot-prognozuye-upovilnennya-zrostannya-svitovoyi-torgivli-poslugami-v-i-kvartali-2020-roku (accessed 05 May 2020).

5. Vedomosti.ru (2019), "Zachem razvivat' jeksport uslug", available at: https://www.vedomosti.ru/opinion/columns/2019/09/30/812490-zachem-razvivat-eksport (accessed 05 May 2020).

6. The World Economic Forum (2020), "Coronavirus could reduce world trade by up to a third, according to the WTO", available at: https://www.weforum.org/agenda/2020/04/wto-financial-crisis-coronavirus-covid19-recession-trade-global/ (accessed 05 May 2020).

7. Statista, Share of commercial services exports worldwide 2014 to 2018 , by category. The Global Statistics Portal. Retrieved from: https://www.statista.com/statistics/649834/share-of-commercial-service-categories-in-world-export-trade/ (accessed 05 May 2020).

8. Reserve Bank of Australia (2019) “The International Trade in Services”, available at: https://www.rba.gov.au/publications/bulletin/2019/mar/the-international-trade-in-services.html (accessed 05 May 2020).

9. Deloitte (2018) "The services powerhouse: Increasingly vital to world economic growth", available at: https://www2.deloitte.com/us/en/insights/economy/issues-by-the-numbers/trade-in-services-economy-growth.html (accessed 05 May 2020). 
10. UNCTAD (United Nations Conference on Trade and Development) "Handbook of Statistics 2019. Total trade in services", available at: https://stats.unctad.org/handbook/Services/Total.html (accessed 05 May 2020).

11. UNCTAD (United Nations Conference on Trade and Development) "Handbook of Statistics 2019. Trade in services by category", available at: https://stats.unctad.org/handbook/Services/Total.html (accessed 05 May 2020).

12. UNCTADstat. Data Center. Available at: https://unctadstat.unctad.org/wds/ReportFolders/reportFolders.aspx?sCS ChosenLang=en (accessed 05 May 2020).

13. World Bank national accounts data, OECD national accounts data files, 2017-2019. Available at: https://data.worldbank. org/indicator/ (accessed 05 May 2020).

14. World's Top Export (2019) "World's Top Export Services”, available at: http://www.worldstopexports.com/worlds-topexport-services/ (accessed 05 May 2020).

15. WTO Data Portal (2020). Available at: https://timeseries.wto.org/ (accessed 05 May 2020).

16. WTO (World Trade Organisation) (2019). Statistics on trade in commercial services. Available at: https://www.wto.org/ english/res_e/statis_e/tradeserv_stat_e.htm (accessed 05 May 2020).

17. WTO (World Trade Organisation) (2020). "Trade set to plunge as COVID-19 pandemic upends global economy", available at: https://www.wto.org/english/news_e/pres20_e/pr855_e.htm (accessed 05 May 2020).

18. WTO (2019). "World Trade Report 2019: The Future of Services Trade". World Trade Organization (WTO), Geneva: Switzerland, Report. See online at: https:/www.wto.org/english/res_e/publications_e/wtr19_e.htm (accessed 05 May 2020).

19. WTO (2019). World Trade Statistical Review 2019, World Trade Organization, Geneva. See online at: https://www.wto.org/english/res_e/statis_e/wts2019_e/wts2019_e.pdf (accessed 05 May 2020).

\section{Vovchanska Olha \\ Lviv University of Trade and Economics \\ Ivanova Liliya}

Lviv State University of Physical Culture named after Ivan Boberskij

\section{MARKET RESEARCH OF SERVICES MARKET: INTERNATIONAL AND NATIONAL ASPECTS}

The article identifies structural changes in the world services market in the international and national aspects and defines the main tendencies of its development. Over the last twenty years, both exports and imports of services have increased 3.6 times, the share of services in the structure of world GDP has been growing steadily, and for many countries it has become the largest employer. The analysis of the dynamics of exports and imports of services has been carried out in the macro-regions of the world and in countries of different levels of economic development. It is determined that Europe remains the epicenter of world trade in services. The second position is occupied by Asia. North America closes the top three in terms of international trade in services. It is noted that industrialized countries retain dominant positions in the world market of services, and countries with economies in transition have the smallest share of the world market of services. Authors has analyzed the rating of countries by indicators of export and import in the world market of services. The structure of the world market of services has undergone significant changes: the share of transport services has decreased to $17 \%$, the share of tourist services is about 25\%, but the share of other services is growing faster and in the structure of world exports they are crucial. Global trends in world trade in general will create the preconditions for the emergence of new types of services, change the demand for services, open new segments of services markets, in particular, in the field of health and environment. In Ukraine there is a constant trend of development of the services sector, the growth rate of which is ahead of the dynamics of GDP. Despite the fact that the export of services shows a growing trend, Ukraine's opportunities to increase the role of services in the economy are far from exhausted. Therefore, strengthening the export orientation of the service sector should become one of the main factors in modernizing the structure of the Ukrainian economy. Authors note that COVID-19 pandemic will have the most negative impact on international trade in services as the result of transport and tourism restrictions and the closure of many retail and hospitality businesses. The resumption of world trade in services is possible by 2021, but this will depend on the duration of COVID-19 and the effectiveness of relevant economic and policy measures, will require deepening cooperation between countries and reducing barriers for mutual trade in the most promising and fast-growing service industries.

Key words: service, world market, international trade, export of services, import of services, marketing researches.

JEL classification: F14, L8, L9, O11. 